\title{
An Analytical Study of Laws, Determining the Gender of a Transgender Person in Pakistan
}

* Dr. Fozia Naseem, Assistant Profess or

** Dr. Rooh ul Amin, Deputy Registrar (Academics) (Corresponding Author)

*** Dr. Ghulam Muhammad Awan

\begin{abstract}
Living organisms are divided into two genders, generally, whether they are plants, animals, birds, insects, or human beings. These two genders are males and females and are often called binary genders. Among the human species, sometimes, babies are born with some disabilities in their reproductive organs and such babies have been there in human societies for a time, unknown. In ancient Arab, these people were called 'khunsas'. They were used as slaves by the royal elite of the Arabic peninsula. Deen-e-Islam has given a large number of rights to khunsas and provides them many opportunities to live with honor and grace. Transgender Persons (Protection of Rights) Act 2018, was the first statute passed by the Parliament of Pakistan that protects and promotes the rights of khunsa people in Pakistan, specifically. In this paper, an effort is made to analyze the principles of Islam and the Laws provided in the Transgender Persons (Protection of Rights) Act 2018, to determine the gender disability of khunsa persons. A comparative study is also a part of this paper on the approach related to gender determination of a khunsa person, between Hanafi School, Itsna Ashari School, and the laws of Pakistan.
\end{abstract}

Keywords: Transgender, Male, Female, Protection of Rights, Hanafi School, Ashari School

\section{Introduction}

Some identities are very important and play a very vital role in our lives like cast, nationality, creed, and most importantly gender. Gender identity is very important in one's life. Human beings are very eager to know the gender of their unborn child and the reason is that the gender of that baby decides the coming life of parents. If it is a baby boy, parents buy boy dresses and toys, and if it is a girl parents used to buy female dresses and toys. Gender is very important for the baby too as gender determines his status in society and his rights and duties in society. Gender identity is a part of the whole identity. The sexual organs of a baby determine gender identity. Presence of male genital means that a baby has a male gender and the presence of female genital means a female gender.

People often, merge gender expression with gender identity but gender expression is absolutely a different idea. Gender expression is how we express our gender through actions and appearance. ${ }^{1}$ It has been observed that people are there in human societies who do not express their natural gender e.g. a male boy expresses himself as a girl by way of his actions i.e. body gestures, dressing or way of talking, etc. these people are not accepted by most of the societies. They are discouraged and face harsh and strict sanctions.

Generally, every living organism has only two pairs. A male and a female and reproduce and give birth to the children to increase their species. Human beings are generally classified into two genders i.e. male and female but transgender is a certain reality of our societies. Transgender is treated as the third gender in western societies and many other countries, NGOs and other pro-transgender societies are working to recognize transgender as a third gender. It is very interesting to know that transgender is an umbrella term under which along with real transgender, eunuchs, crossdressers, third gender and intersex take shelter. ${ }^{2}$ Sometimes, gays, lesbians, and bisexuals also use the term

\footnotetext{
1 “Definitions." UN Free \& Equal. UNFE, n.d. https://www.unfe.org/definitions/.

2 ibid
}

\footnotetext{
* College of Law, Government College University, Faisalabad, Pakistan Email: fiza.adv@gmail.com

** University of Wah, Wah Cantt, Pakistan Email: rua58@yahoo.com

*** Department of Peace \& Conflict Studies, National Defense University (NDU), Is lamabad, Pakistan Email: sizova79@hotmail.com
} 
transgender for themselves but this is not the exact term for them rather globally the term LGBT is used for such persons.

Being a gay, lesbian, transsexual, or bisexual is not a biological issue but a psychological issue. They are the behaviors, which are developed or adopted under the influence of some very strong motivation. In Islam, these behaviors are not treated as a gender rather Islam only recognizes two genders, first is male, and the second is female.

Being transgender does not mean a curse or behavior but it is a disability like any other birth disability. Scientifically such disability is because of a change in the fixed ratio or quantity of chromosomes i.e. a female has two same XX chromosomes in her DNA and they are called homogametic sex. A male has two different $\mathrm{X}$ and $\mathrm{Y}$-chromosomes in his DNA are they are called heterogametic sex. When male sperms fertile female egg, the birth of a baby starts. If a baby has XX chromosomes, it will be a female and if a baby has, $\mathrm{X}$ and $\mathrm{Y}$-chromosomes then it will be a male. Sometimes a disorder occurs in this ratio and such disorder results in an extraordinary change in the life of such unborn child. If this ratio of chromosomes increases to three i.e. three same XXX chromosomes or three XXY chromosomes, then as result the baby will be transgender. If such baby physically looks like a male, his behavior would be of a female and if such baby physically looks like a female his behavior would be of a male.

\section{Identifying a Transgender in Islam}

Islam is a very versatile and unique religion. It has discussed and elaborated every topic of human life and human society and the things or issues, which are not discussed expressly, can be found impliedly by the way of Ijtihad and Ijma from hadith and Quran. Although the directions and commands about transgender people are rarely found in Quran and Sunnah but yet the available commands are sufficient to make a decree or to establish an opinion over the issues which are related to these marginalized persons.

Transgender persons are easily found in every human society indeed and they were present in the city of Madina and Makkah too. At that time they were slaves, guards, or army personals and they were not honored and regarded humanly. After the advent of Islam, a need was there to understand the rights, status, and duties of these persons. The most important thing to understand was the procedure and standards to determine the gender of such persons to understand their status while deciding their rights. According to Is lamic jurists, there are five types of transgender. Their details and procedure to determine their gender is given under.

\section{Male Transgender}

Such a transgender who is transgender by birth and physically has male characteristics is a male transgender. Such transgender is very rare and there is only one male transgender out of one thousand transgender. Such people have very small genitals or sometimes there is no genital at all and because of this reason, these people are not able to marry.

\section{Female Trans gender}

Such a transgender who is a transgender by birth and physically has female characteristics is a female transgender but their reproductive organs are not complete. Such transgender has grown breasts and a feminine face.

\section{Khunsa or Intersex}

Khuntsa means soft or flexible. Technically a person is called Khunsa who have both male and female genitals by birth or having no genital at all. As a khunsa has two genitals, it is very difficult to determine his gender.

Khunsa is further divided into three categories i.e. khunsa male, khunsa female, and khunsa mushkil. In Islamic law, the determination of the sex of khunsa is on two stages. The first stage is before the age of puberty and the second stage is after the age of puberty.

Dete rmination of Gender before the Age of Puberty (Hanafi School):

Before the age of puberty, a determination is done by examining the urination. If such person urinates from the male genital then such person shall be treated as a male. If urination is from the female genital then such a person has to be treated as a female. ${ }^{3}$

According to Imam Abu Hanifa, khunsa is such a person who has both a vagina and a penis. The sex of such a person can be determined by examining his way of urination. If transgender urinates

\footnotetext{
${ }^{3}$ Ali bin Abi Bakkar, Buhanudin. Al HIdaya Fi Sharah Bidayatul Mabtadi, Kitabul Khunsa. Edited by Al Murghiani. Vol. 1. Beirut: Darul Ahyaul Tarasul Arabi
} 
from the urethra, she is a female and if transgender urinates from the urethral then he is a male. The complex case is when such transgender urinates from both the urethra and urethral. In such a case if he urinates first from the urethral then he is a male and if urinates first from the urethra then she is a female. The case becomes more complex if a transgender urinates from both male and female organs at the same time. According to Imam Abu Hanifa, the sex of such a transgender cannot be determined. Some jurists of Hanafi School agreed that quantity of urine will determine the gender of such transgender i.e. if such a transgender urinates more from the urethra, she is female and if such a transgender urinates more from the urethral, then he is a male. ${ }^{4}$ However, the consensus of the majority is upon the opinion of Imam Abu Hanifa that a khunsa who urinates from both male and female organs is a khunsa Mushkil.

Qadri Pasha writes in 'Al Ahkamul Sharia Fil Ahwalul Shakhs iat' that Khunsa is a person who has both male and female genitals or has no genital at all. So if such person urinates from the male genital then he will be treated like a male and if urination is from female genital then she will be treated as a female but if such person urinates from both genitals at the same time, then such person is a khunsa mushkil. ${ }^{5}$

\section{De te rmination of Gender after the Age of Puberty (Hanafi School):}

After the age of puberty, if a khunsa gets a beard or if becomes able to have sex with a female or ejaculates from the urethral then such transgender will be treated as a male. If a khunsa gets breasts like females or gets menstruations then such a transgender will be treated as female. If no male or female physical signs appear, then such a khunsa shall be treated as Khunsa Mushkil. ${ }^{6}$

According to the School of Anhaaf, if a beard, masculine body, sex with a female are the characteristic of a male and all these signs are evidence that a transgender is a male transgender. Developed breasts like women, pregnancy, and menstruation are the characteristics of a female and thus these signs are evidence that a transgender is a female transgender. The absence of these signs at all means that such a transgender is a khunsa mushkil. ${ }^{7}$

Qadri Pasha writes in 'Al Ahkamul Sharia Fil Ahwalul Shakhsiat' that if a transgender gets a beard after attaining the age of puberty, or if he does sex with a woman, or if ejaculates from urethral, in all or any of these cases, such person will be treated as a male transgender. If a transgender upon attaining the age of puberty, gets breasts like females, has menstruation, gets pregnant or if gets a developed vagina then such a transgender will be treated as a female transgender. If none of the said signs appear then such person will be treated as khunsa mushkil. ${ }^{8}$

De te rmining Gender of Transgender (itsna Ashari School):

According to Itna Ashari School of Imam Jafar Sadiq, the gender of khunsa Mushkil is determined by examining the urination and procedure is same as of School of Anhaaf but in this school four steps are given.

1. The path of urination will determine the gender of a transgender. If he urinates from the male part, he is a male and if urinates from the female part, then such transgender is a female. ${ }^{9}$

2. If a khunsa urinates from both sexual parts then the dominant part will determine the gender. The part from which urination starts at first will be the dominant part. It means that if urination starts from the male part first, such transgender will be treated like a male and if urination starts from the female part at first, such transgender will be treated as a female. ${ }^{10}$

3. If a khunsa urinates from both sexual parts and urinates start from both parts at the same time then, the ending of urination will determine the dominant part. It means if urination ends from the female part first and the male part later, such transgender will be treated as male

\footnotetext{
${ }^{4}$ Ahmad bin Muhammad, Abul Hassan. "Kitabul Khunsa." In Al Mukhtasa Al Qadoori, 124-24. Quetta: Maktaba Alrashidiya

${ }^{5}$ Pasha, Qadri. Al Ahkamul Shariah Fil Ahwalul Shaksiyah. Egypt: Matbua Misar, 1895.

${ }^{6}$ Ali bin Abi Bakkar, Buhanudin. Al HIdaya Fi Sharah Bidayatul Mabtadi, Kitabul Khunsa. Edited by Al Murghiani. Vol. 1. Beirut: Darul Ahyaul Tarasul Arabi

7 Ahmad bin Muhammad, Abul Hassan. "Kitabul Khunsa." In Al Mukhtasa Al Qadoori, 124-24. Quetta: Maktaba Alrashidiya

${ }^{8}$ Pasha, Qadri. Al Ahkamul Shariah Fil Ahwalul Shaksiyah. Egypt: Matbua Misar, 1895.

${ }^{9}$ Al Najafi, M Hussain. Qawaneen Al Shariah Fi Fiqa Jafriyah. Vol. 2. Sargodha: Maktaba Alsibtain, 2010.270

${ }^{10}$ Ibid.
} 
transgender. If urination ends from the male part first and the female part later, then such transgender will be treated as a female transgender. ${ }^{11}$

4. If urination starts and ends at the same time then other factors like beard, developed breasts, menstruation will be considered to determine the gender. ${ }^{12}$

5. If all the above four methods fail to determine or recognize the gender of a khunsa, then such khunsa will be treated as Khunsa Mushkil. ${ }^{13}$

Unlike Hanafi School, In Shia School, whether the question of determining the gender is before the age of puberty or whether it is after attaining the age of puberty, for both procedures is the same.

\section{Narban or Hijras}

The third type of transgender according to Islamic jurists is Narban. The word Narban is composed of two Urdu words 'Nar' which means a male and 'Qurban' which means sacrifice. Narban is used to refer to a person who has sacrificed his maleness to join the group or tribe of transgender. This procedure is done by castration but such castration is done by the transgenders themselves and not by the professional surgeons.

\section{Aqwayi or Mukhanath}

The Aqwayi or Mukhanath are the people who are not transgender by birth and they do not castrate themselves to join the group of transgender. They are the people, who are influenced by the transgenders and imposter themselves like transgenders and such people are called 'Zanana'. Some people are motivated by the transgender to join themselves to earn livelihood and such motivated people are called 'Zankha'. It should be noted that a Mukhanth could be of feminine characteristics by nature and in such a case there is no sin for him but if a person adopts such behavioral characteristics as discussed above, then such an act is prohibited in Islam.

\section{Gender Identification According to Section 3 of TPPA 2018}

Transgender Persons (Protection of Rights) Act, 2018 was the first legis lative development that deals specifically with the rights of transgender persons. Its objective is to give protection and relief to a transgender person in all the cases where needed and to rehabilitate the transgender persons to make them enable to actively participate in society to regain their dignity and honor.

Section 3 of this act gives the procedure to identify and recognize the gender of a transgender person. Section 3 is TPPA 2018 is further divided into four clauses. According to clause one of section 3, a right is given to the transgender himself to recognize his gender. It means, that a transgender can adopt any gender of his choice without any medical examination and only a mere declaration of such a transgender is enough.

According to the second clause of section 3, a transgender person has the right to registered himself into NADRA (National Database and Registration Authority) and any before any other department or institution if needed according to his self-perceived gender.

The third clause of section 3 tells that a transgender has to adopt the proper procedure for registering himself before any authority e.g. if a transgender wants to register himself in NADRA, he has to adopt the manner that is written in the relevant law i.e., in this case, NADRA Ordinance 2000. Similarly is a transgender wants a driving license, Child Registration Certificate (CRC), or a passport, such transgender has to adopt the same manner and channel that is adopted by other ordinary persons. Only one discrimination is given to transgender persons, that they can choose the gender of their own choice.

The fourth clause of section 3 gives the right to a transgender person who has been issued a CNIC already and he wants to change his gender or name, then he can change his name or gender according to his perception. Again, such transgender has to follow the procedure which is given in NADRA Ordinance 2000 to change his name or gender.

\section{Conclusion}

No doubt, the procedure is given by Muslim jurists to identify and determine the gender of a transgender is conventional but still, it provides a prima facie detail method and detail for the assignment of sex or gender to a transgender person. Islam has never stopped Muslims to ponder over things, again and again, to modify the ir knowledge rather all the time, it encourages and motivates

\footnotetext{
${ }^{11}$ Ibid.

12 Ibid.

${ }^{13}$ Ibid.
} 
them to think over the creation, universe, and the things present in them. One can easily find it that proves and evidence is there in the Islamic history that it was the first religion that speaks for the rights of transgender, that determines them as male and female and not as a curse or third gender and also given them rights equivalent to normal males and females.

\section{Recommendations}

\section{Standards of Medical B oard}

The medical board established under TPPA 2018, must follow the standards, laid down by Hanafi and Itsna Ashari School in true letter and spirit and psychological standards must be discouraged.

\section{Confusion between Gender and Sex}

One of the most confusing things in reading and comparing TPPA 2018 with International literature and international laws is the confusion of sex and gender. TPPA 2018 uses the word 'identification of gender' rather than sex. Gender is the adopted behavior of a person in a society e.g. if a body adopts the traits of a girl due to nurturing or due to any psychological issue then such boy has male sex but female gender. On the other hand, sex is a biological trait of a person and can never be changed until or unless by way of gender reassignment surgery. This confusion must be corrected and needs to be changed. As English is not the native language of the people of Pakistan, the word 'sex' should be used instead of 'gender'.

\section{Awareness Lessons in the Educational Curriculum}

Education and awareness is the ultimate solution to resolve a problem. There must be compulsory awareness programs for the students of higher education, for officeholders, and especially for the officers of civil services and judiciary. This kind of program will change the dimension and thoughts of the public towards this marginalized community. Dengue awareness program in Province Punjab is a recent example to eradicate dengue from the province. For the betterment and for the social uplift of the transgender community such programs are essential.

\section{References}

Ali bin Abi Bakkar, Buhanudin (n.d). Al HIdaya Fi Sharah Bidayatul Mabtadi, Kitabul Khunsa. Edited by Al Murghiani. Vol. 1. Beirut: Darul Ahyaul Tarasul Arabi

Bin Muhammad. A., Hassan. A. (n.d). "Kitabul Khunsa." In Al Mukhtasa Al Qadoori, Quetta: Maktaba Alrashidiya

Najafi, A. M Hussain (2010). Qawaneen Al Shariah Fi Fiqa Jafriyah. Vol. 2. Sargodha: Maktaba Alsibtain,.

Pasha, Q. (1895) Al Ahkamul Shariah Fil Ahwalul Shaksiyah. Egypt: Matbua Misar, 1895. "Definitions." UN Free \& Equal. UNFE, n.d. https://www.unfe.org/definitions/. 